\title{
Characterization of Biotic and Abiotic Profiles of Greenhouse Evaporative Cooling System Fouling
}

\author{
AA Nuhu*1 and S Ahmad² \\ ${ }^{1}$ Biology Programme, ${ }^{2}$ Environmental Management Technology, Abubakar Tafawa Balewa University, Bauchi, Bauchi \\ State, Nigeria
}

\begin{abstract}
Purpose: To characterize the microorganisms influencing greenhouse evaporative cooling system fouling as a prelude to designing a sustainable remediation scheme that would assist in reducing the heavy financial loss incurred by stakeholders due to deterioration of cooling pads.

Methods: Samples of biofilms on evaporative cooling system pads were collected from various locations in Saudi Arabia and fixed with 5\% formaldehyde. Light microscopy, scanning electron microscopy (SEM) and QWIN software were employed for the identification of different morphometric parameters of the constituent microbes. $\mathrm{pH}$ and conductivity were assessed using Pasport PS-2102 and PS-2116 sensors, respectively.

Results: Different genera of cyanobacteria and diatom including Phormidium, Oscillatoria, Lyngbya, Navicula, Melosira and Gomphonema were identified and characterized, in addition to various types of bacteria and white crust fungus, Phanerochaete crysosporium. Total dissolved solids (TDS) values of $2641 \mathrm{ppm}$ (conductivity, $5282 \mu \mathrm{S} / \mathrm{cm}$ ) for Al-Rasheed, $2327.5 \mathrm{ppm}$ (conductivity, $4655 \mu \mathrm{S} / \mathrm{cm}$ ) for Sara, $3352 \mathrm{ppm}$ (conductivity, $6704 \mu \mathrm{S} / \mathrm{cm}$ ) for Dammam Municipality Greenhouse (DMG) and $61.5 \mathrm{ppm}$ (conductivity, $123 \mu \mathrm{S} / \mathrm{cm} ; \mathrm{pH} 6.88$ ) for KFUPM were obtained at $25^{\circ} \mathrm{C}$.

Conclusion: Various organisms, including cyanobacteria and diatoms, which have been implicated in the biofilms of evaporative cooling systems at different locations in Saudi Arabia, were characterized with the aid of morphometric parameters. Identifying the constituent microorganisms would aid in designing a sustainable remediation scheme that is expected to reduce the heavy financial cost incurred by stakeholders due to frequent replacement of evaporative cooling pads during routine maintenance.
\end{abstract}

Key words: Cyanobacteria, Diatoms, Biofilms, Morphometric, Evaporative cooling

*Corresponding author: Email: aanuhu@yahoo.com; Tel: +234-807-250-8912 


\section{INTRODUCTION}

In arid regions, such as Saudi Arabia, where temperatures could some times exceed $40^{\circ} \mathrm{C}$, greenhouses are often equipped with evaporative cooling systems to provide good condition for workers as well as to prevent desiccation of plant materials. The efficiency of evaporative cooling pads in such systems greatly depends on how freely air can pass through them ${ }^{1}$. This efficiency is frequently thwarted by the daunting challenge of algal and bacterial growth which shortens their lifespan, leading to decreased cooling potentials of such pads ${ }^{2}$. This problem causes a lot of economic damage to the stakeholders. Biofouling is a phenomenon used to describe the nuisance deposition and formation of biofilms on solid supports ${ }^{3}$. Biofilms are heterogeneous and are found in diverse environments ${ }^{4}$. They are often characterized based on their complex community relationships, morphological differences, genetic diversity, or complex polymeric materials. The diverse extra cellular polymeric materials allow the microorganisms to perform various functions including attachment to solid platforms ${ }^{5}$. Nearly all kinds of microorganisms, ranging from algae to bacteria, can infest and cause clogging and degradation of materials including the evaporative cooling pads. Even though evaporative cooling system fouling can result from trapping of debris, silt, salt and scale by the cooling pads, the presence of biofilms makes the process a very daunting and complex one.

Bacterial biofilms often contain photosynthetic cyanobacteria. These are very small and usually unicellular, though they can also form colonies large enough to be seen with the naked eyes. Also found among biofilms is an important group of eukaryotic algae known as diatoms. They have a penchant for aggregation and sinking made possible through the production of mucilage or heavy resting spores ${ }^{6}$.

\section{MATERIALS AND METHODS Sample collection and treatment}

Samples of biofilm on evaporative cooling system pads from the King Fahd University of
Petroleum and Minerals (KFUPM) greenhouses, Sara Farms in Al-Kharj, AlRasheed Farms in Aziziya (Dhurma) and Dammam Municipality Greenhouse (DMG) were collected by scrapping with clean forceps. Sampling was done randomly both from the inside and outside surfaces having different degrees of light exposure. Samples were fixed with $5 \%$ formaldehyde solution and stored in stoppered bottles at $5^{\circ} \mathrm{C}$ of a Biotronette Plant Growth Chamber.

\section{Sample preparation for light microscopy}

The sample was prepared for light microscopic examination according to standard protocols ${ }^{7}$. Briefly, thin sections of the cooling system pads above were removed by forceps on to a microscope slide and then covered with a cover slip. Drops of glycerin were added to the edge and allowed to sip inside by capillarity. The slide was then observed under the Zeiss light microscope at $40 \mathrm{X}$. Visible microorganisms were captured using the attached digital camera TKC 1380.

\section{Sample preparation for scanning electron microscopy}

After fixing the samples in 5\% formaldehyde solution, they were subjected to different concentrations of alcohol, 25\%, 50\%, 75\% and $95 \%$, for dehydration, followed by acetone in the final step consecutively, as earlier described $^{8}$. The samples were then goldcoated and examined in SEM Jeol JSM-5900 $\mathrm{LV}$ operating at $20 \mathrm{kV}$. Different portions of the images were analyzed for mineral clues using energy- dispersive X-ray spectroscopy.

\section{Morphometrics of cyanobacteria and diatoms}

For cyanobacteria, cell width and cell length of Apical (A) and Vegetative (V) cells were measured using QWIN image analysis software; for diatoms frustules, apical(A), central $(C)$ and lateral length( $L)$ of identified organisms were measured- the ratios of $\mathrm{C} / \mathrm{L}$ and $A / C$ were also calculated. For each measurement, 25 replicates were taken and their mean and standard deviation calculated. The mean cell length values were then plotted against the mean cell width values. 


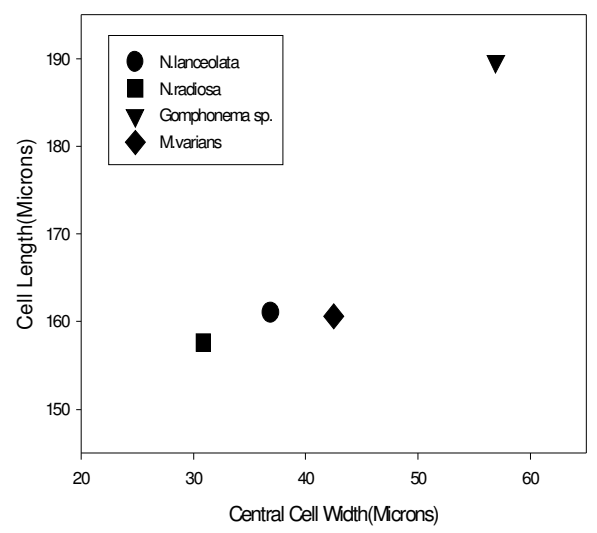

Fig 1: Plot of morphometric data for four species of diatoms in the biofilm of University Greenhouses 1 \& 3 . Cell Length versus Central Cell Width measurements are plotted and summarized as means for the parameters. Circle $=$ Navicula lanceolata, Square $=N$. radiosa, Triangle down $=$ Gomphonema $s p$. and Diamond= Melosira varians

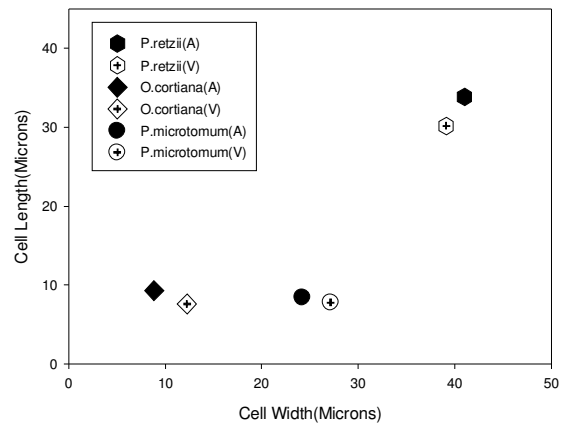

Fig 2: Plot of morphometric data for three species of cyanobacteria in the biofilm of University Greenhouses 1 \& 3. Cell Length versus Cell Width measurements are plotted and summarized as means for Vegetative (V) and Apical (A) cell types: Hex, Diamond and Circle for Phormidium retzii, Oscillatoria cortiana and P. microtomum respectively. $\mathrm{X}$-hair=vegetative and without $\mathrm{x}$ - hair=apical.

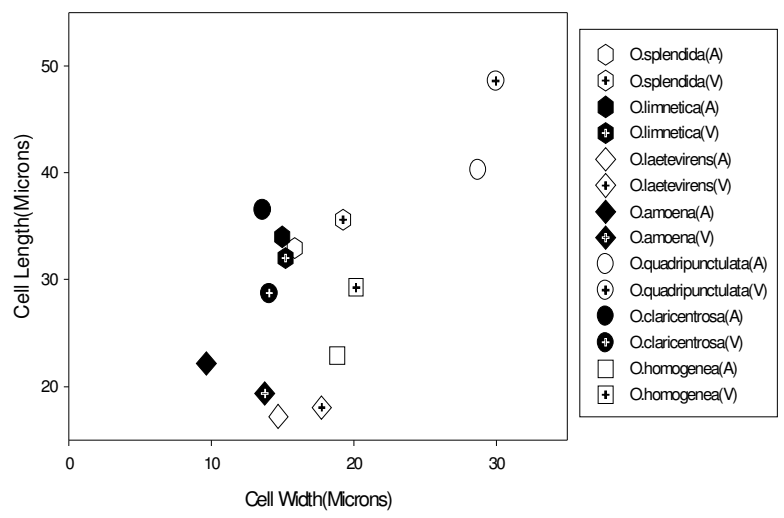

Figure 3: Plot of morphometric data for seven species of Cyanobacteria in the biofilm of Al-Rasheed Farms. Cell Length versus Cell Width measurements are plotted and summarized as means for Vegetative (V) and Apical (A) cell types: Hex white=Oscillatoria splendida, Hex black= O. limnetica, Diamond white=O.laetevirens, Diamond black=O.amoena, Circle white=O.quadripunctulata, Circle black= O.claricentrosa, and Square white=O.homogenea; with $\mathrm{x}$-hair=vegetative and without $\mathrm{x}$-hair=apical. 


\section{Water quality examination}

Water samples from the various greenhouses were collected and analyzed for $\mathrm{pH}$, conductivity and total dissolved solids (TDS). This was aimed at determining the effect that any differences in composition of the water samples might have on the development of biofilms, as well as on the enhancement of deposition. Conductivity and $\mathrm{pH}$ were estimated using Pasport PS-2116 Conductivity sensor and PS-2102 pH sensor respectively. All measurements were carried out at room temperature $\left(25^{\circ} \mathrm{C}\right)$. The respective TDS of each water sample was then calculated from its conductivity value.

\section{RESULTS}

Different genera of cyanobacteria and diatom including Phormidium, Oscillatoria, Lyngbya, Navicula, Melosira and Gomphonema were identified and characterized at different conditions of total dissolved solids and $\mathrm{pH}$. TDS values of 2641 ppm (conductivity, 5282 $\mu \mathrm{S} / \mathrm{cm}$; pH 8.13) for Al-Rasheed, $2327.5 \mathrm{ppm}$ (conductivity, $4655 \mu \mathrm{S} / \mathrm{cm}$; pH 8.04) for Sara , 3352 ppm (conductivity, $6704 \mu \mathrm{S} / \mathrm{cm}$; pH 7.08) for Dammam Municipality Greenhouse (DMG) and 61.5 ppm ( conductivity, 123 $\mu \mathrm{S} / \mathrm{cm}$; $\mathrm{pH} 6.88$ ) for KFUPM were obtained at $25^{\circ} \mathrm{C}$. The results for the morphometric presentation of these various organisms are given on Figures 1-5, which were summarized and plotted as means of different cell parameters characteristic of the identified microorganisms.

\section{DISCUSSION}

Our findings revealed that the various greenhouses were rich in different species of cyanobacteria and less in species of diatoms. This was possibly due to the high degree of solar irradiation to which our greenhouses are exposed year round. Though diatoms can acclimatise to certain light levels by varying the ratio of diadinoxanthin: chlorophyll $a^{9}$, they are however more efficient in low irradiances $^{10}$, which was not the case with our reference sites. This limited occurrence and distribution of diatoms was further substantiated from the results of our subsequent study and phylogenic analysis, even as these revealed the presence of Shingomonads, Acidobacteria and Flexibacteria (unpublished data). We observed from the scatter plot in Figure 1 that all the diatoms identified in this study have a $\mathrm{C} / \mathrm{L}$ ratio of $\leq 0.3$ and $\mathrm{A} / \mathrm{C}$ ratio of less than 1 ; however, the more the value tends to 1 , the higher the likelihood of the microorganism assuming a rectangular shape, as depicted by Melosira varians. It is noteworthy to indicate that with the exception of Melosira varians, all other species of diatoms identified have $A / C$ ratio of less than 0.5 , necessitating the microbes to take other conformations such as rhombic and lanceolate, whether or not they are isopolar or heteropolar, isobilateral (symmetrical) or dorsoventricular (asymmetrical) ${ }^{11}$. On the other hand, Figure 2 shows the parameters in the University greenhouses for the identified cyanobacteria, with cell length between 6.67 and 37.48 microns as against between 9.98 and 43.57 microns for the cell width. Conversely, Al-Rasheed Farms recorded the range of 15.73-55.83 microns for cell length as against 17.99-32.80 microns for cell width (Figure 3 ).

Figure 4 depicts the cell parameters for the cyanobacteria in Sara Farms; 12.37-33.52 microns for cell length and 5.40-22.64 microns for cell width. Dammam Municipality greenhouse followed somewhat the same trend; while the range of 7.56-23.13 microns was recorded for cell length, 10.43-22.84 microns was registered for the cell width of cyanobacteria therein (Figure 5).

Moreover, analysis of the water used for evaporative cooling at the various locations revealed an acidic $\mathrm{pH}$ and a low TDS value for King Fahd University of Petroleum and Minerals (KFUPM) as against alkaline $\mathrm{pH}$ values and the presence of high values of TDS for the other greenhouses. This difference may be partly due to the hardness of ground water used for evaporative cooling in the latter case. As a result, this may be expected to contribute to the deterioration of cooling pads due to the trapping of precipitated salt in the extracellular polymeric substances produced by the organisms ${ }^{12}$. It 


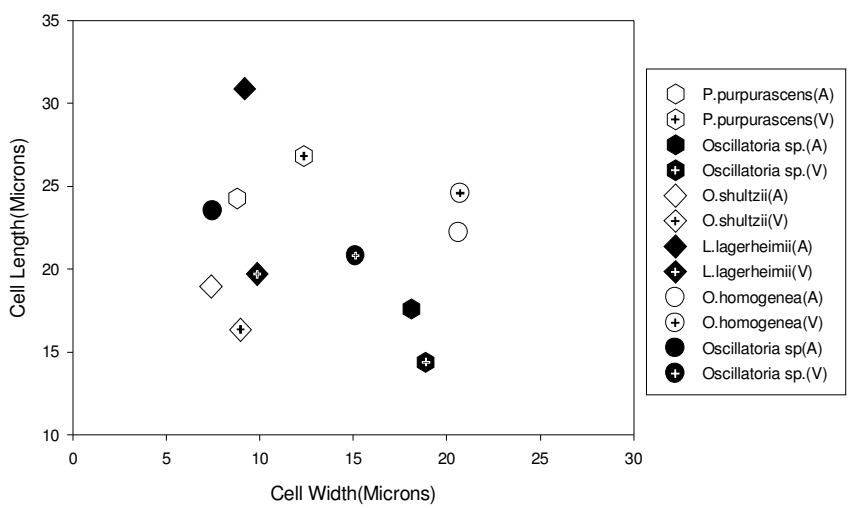

Fig 4: Plot of morphometric data for six species of Cyanobacteria in the biofilm of Sara Farms. Cell Length versus Cell Width measurements are plotted and summarized as means for Vegetative (V) and Apical (A) cell types: Hex white=Phormidium purpurascens, Hex black=Oscillatoria $s p$, Diamond white $=$ O. shultzii, Diamond black=Lyngbya lagerheimii, Circle white=O.homogenea, Circle black=Oscillatoria $s p$.; with $\mathrm{x}$ hair $=$ vegetative and without $x$ - hair $=$ apical

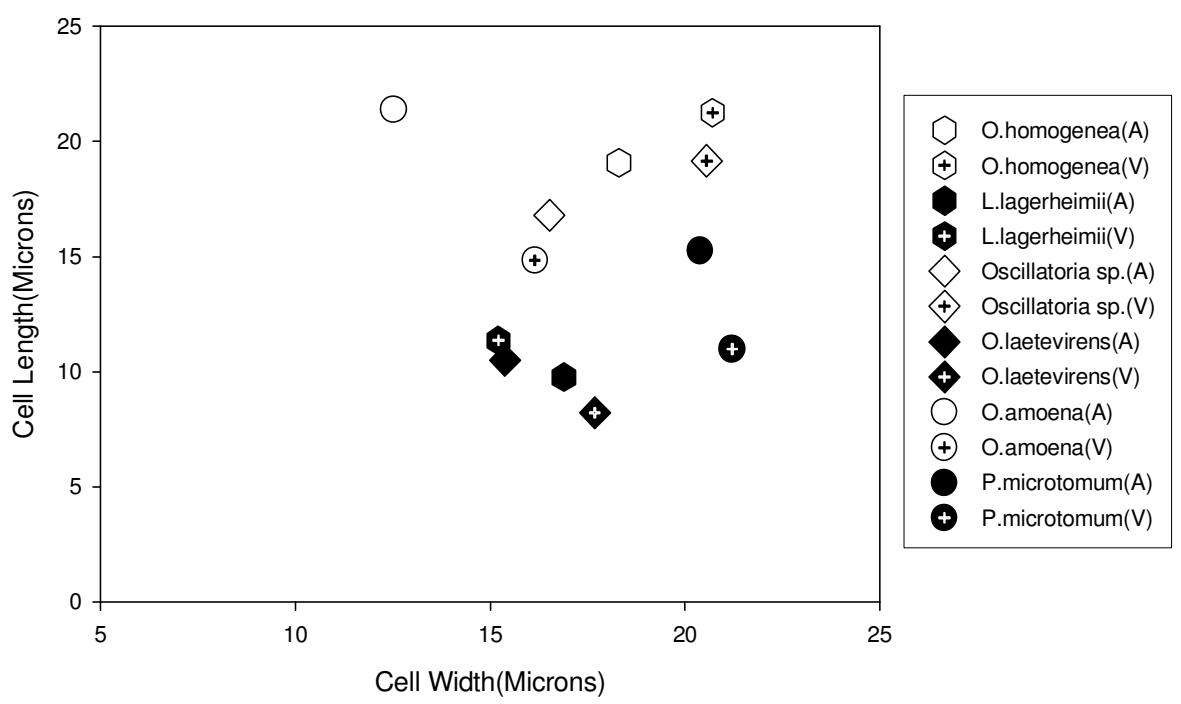

Fig 5: Plot of morphometric data for six species of Cyanobacteria in the biofilm of Dammam Municipality Greenhouse. Cell Length versus Cell Width measurements are plotted and summarized as means for Vegetative (V) and Apical (A) cell types: Hex white=Oscillatoria homogenea, Hex black=L.lagerheimii, Diamond white $=$ Oscillatoria sp., Diamond black=O.laetevirens, Circle white $=$ O. amoena, Circle black=Phormidium microtomum; with $\mathrm{x}$-hair=vegetative and without $\mathrm{x}$ - hair=apical.

may also account for the difference in values of TDS and $\mathrm{pH}^{13}$. Analysis of SEM distribution of cyanobacteria and diatoms at images using energy-dispersive $X$-ray the various greenhouses, as some spectroscopy further confirmed the presence cyanobacteria can be very adaptive to higher of mineral salts in those biofilm samples. 
Coccoid and colony-forming filamentous cyanobacterial biofilms have been reported on salted portion of limestone buildings ${ }^{14}$. Using transmission electron microscope, Konhauser et al. ${ }^{15}$ have shown that mineralization of the Cyanobacterium calothrix species took place entirely on the extra-cellular polymeric substance (EPS) of the bacterium.

The most commonly used material for greenhouse cooling pads is corrugated cellulose fabric, which is susceptible to deterioration over time. In addition to the characterized Cyanobacteria, we observed the presence of white-rot fungus, Phanerochaete chrysosporium, in the biofilm sample from Sara Farm. This fungus is capable of developing biofilms and producing hydrolytic enzymes even on ceramic and polysulphone membranes ${ }^{16}$. In an experiment to assess the degrading potential of $P$. chrysosporium, it was found that the fungus was faster in forming biofilms when compared to other fungi, and effectively achieved reduction in the lignin content of pulp mill wastewaters by about $71 \%{ }^{17}$. Since most of the cooling pads in this part of the globe (Saudi Arabia) are made of cellulose, it may be disturbing to note that $P$. chrysosporium has the potential for enhancing crystalline cellulose degradation by cellulases ${ }^{18}$.

Although air-conditioning and refrigeration systems can also be employed in achieving greenhouse cooling, it is unfortunate that the installation and operating costs of these systems make them less favorable in greenhouse applications ${ }^{2}$.

\section{CONCLUSION}

Various organisms, including cyanobacteria and diatoms, which have been implicated in the biofilms of evaporative cooling systems at different locations in Saudi Arabia, were characterized with the aid of morphometric parameters. Identifying the constituent microorganisms would aid in designing a sustainable remediation scheme that is expected to reduce the heavy financial cost incurred by stakeholders due to frequent replacement of evaporative cooling pads during routine maintenance.

\section{ACKNOWLEDGMENT}

The authors gratefully acknowledge Mr. Mushabbab Assiri for helping with SEM. The work presented here was supported by College of Sciences, KFUPM, through a research Grant for a project titled "New techniques for characterization and remediation 2005/6".

\section{REFERENCES}

1 Kittas $C$, Bartzanas $T$, Jaffrin $A$. Greenhouse evaporative cooling: measurement and data analysis. American Society of Agricultural and Biological Sciences. 2001; 44(3): 683-689

2 Bucklin RA Leary JD, McConnell D.B, Wilkerson EG. Fan and Pad Greenhouse Evaporative Cooling Systems. Department of Agricultural and Biological Engineering, Florida Cooperative Extension Service, Institute of Food and Agricultural Sciences, University of Florida, Circular 1135. 2004.

3 Lewandowski Z, Stoodley P, Roe F. Internal Mass Transport in Heterogeneous Biofilms: Recent Advances. Corrosion. Paper No 222, Texas: NACE. 1995.

$4 \quad$ Lutterbach MTS, de Franca FP. Biofilm formation on Brass coupons exposed to cooling water. Braz J Chem Eng. 1997; 14 (1):81-87

5 Murphy FT, Kirkham C. Biofilm formation by nontypeable Haemophilus influenzae: strain variability, outer membrane antigen expression and role of pili. BMC Microbiology. 2002; 2:7

6 Smetacek V. Biological oceanography: diatoms and the silicate factor. Nature. 1998; 391:224-5

7 Al-Thukair AA, Golubic S. Five new Hyella species from Arabian Gulf. Algological studies. 1991; 64:167-197.

8 Al-Thukair AA. Effect of oil pollution on euendolithic cyanobacteria of the Arabian Gulf. Environmental Microbiology. 2002; 4(2):125129

9 Dickman MD, Mervyn Richard Peart RM, Yim WW. Benthic Diatoms as Indicators of Stream Sediment Concentration in Hong Kong. International Review of Hydrobiology. 2005; 90(4): 412-421

10 Barranguet $C$, Veuger $B$, Sebastien $A M$, Van Beusekom AS, Marvan P, Sinke JJ Admiraal $W$. Divergent composition of algal-bacterial biofilms developing under various external factors. European Journal of Pycology. 2005; 40(1):1-8

11 Barber GH, Haworth YE. A guide to the morphology of Diatom Frustule. Freshwater Biological Association Scientific Publication No.44. 1981, pp 12-30

12 Ayyyldyz T, Tekin E, Friedman GM. Microtextural properties of ooid in the middle Jurassic -lower Cretaceous, central Taurus carbonate platform, 
Nuhu \& Ahmad

Antalya, Turkey. Carbonates and Evaporites. 2001; 16(1): 1-7

13 Mao TK, Van de Water J, Gershwin ME. Effects of Spirulina-based dietary supplement on cytokine production from allergic rhinitis patients. $J$ Med Food. 2005; 8(1): 27-30

14 Ortega-Morales BO, Gaylards CC, Englert GE, Gaylards PM. Analysis of salt-containing biofilms on limestone buildings of the Mayan culture at Edzna, Mexico. Geomicrobiology Journal. 2005; 22: 261-268

15 Konhauser KO, Jones B, Phoenix VR, Ferris G, Renaut $R W$. The microbial role in hot spring silicification. Ambio. 2004; 33(8): 552-558
16 Sheldon MS, Small HJ. Immobilization and biofilm development of Phanerochaete chrysosporium on polysulphone and ceramic membranes. Journal of Membrane Science. 2005; 263(1-2): 30-37

17 Wu J, Xiao YZ, Yu HQ. Degradation of lignin in pulp mill wastewaters by white-rot fungi on biofilm. Bioresource Technology. 2005; 96(12): 13571363

18 Bao W, Renganathan V. Cellobiose oxidase of Phanerochaete chrysosporium enhances crystalline cellulose degradation by cellulases. FEBS Letters. 1992; 302(1): 77-80 